\title{
The Evolution From Traditional to Online Professional Development: A Review
}

Joshua C. Elliott

Fairfield University, jelliott@fairfield.edu

Follow this and additional works at: https://digitalcommons.fairfield.edu/education-facultypubs Copyright (c) 2017 Informa UK Limited

The author post-print has been archived here with permission from the copyright holder.

\section{Peer Reviewed}

\section{Repository Citation}

Elliott, Joshua C., "The Evolution From Traditional to Online Professional Development: A Review" (2017). GSEAP Faculty Publications. 130.

https://digitalcommons.fairfield.edu/education-facultypubs/130

\section{Published Citation}

Elliott, Joshua C. "The Evolution From Traditional to Online Professional Development: A Review." Journal of Digital Learning in Teacher Education 33.3 (2017): 114-125.

This item has been accepted for inclusion in DigitalCommons@Fairfield by an authorized administrator of DigitalCommons@Fairfield. It is brought to you by DigitalCommons@Fairfield with permission from the rightsholder(s) and is protected by copyright and/or related rights. You are free to use this item in any way that is permitted by the copyright and related rights legislation that applies to your use. For other uses, you need to obtain permission from the rights-holder(s) directly, unless additional rights are indicated by a Creative Commons license in the record and/or on the work itself. For more information, please contact digitalcommons@fairfield.edu. 
The Evolution From Traditional to Online Professional Development: A Review

\author{
Joshua C. Elliott \\ Fairfield University
}

\begin{abstract}
Online professional development offers opportunities for growth to teachers who may not be able to participate otherwise due to constraints. These constraints include, but are not limited to, time and travel distance. This document is a narrative review of relevant literature as it relates to the evolution of teacher professional development. This evolution goes from the historical aspects of professional development through online professional development and its various modes of delivery. This discussion includes research-based perspectives of qualities found in effective professional development, specifically online professional development. Literature relating to some legislation and other guiding factors in the evolution of professional development is also discussed.
\end{abstract}

Teachers must stay current in the different aspects of education to be effective in the classroom (Chung \& Kim, 2010; Ducharme, Ducharme, \& Dunkin, 2002; National Staff Development Council, 2001; The Content of Professional Development for Change Toward Differentiation, 2008). Time constraints often hinder teachers' abilities to initiate meaningful professional development other than what administrators incorporate into the school schedule. As a result, administrators often dictate district professional development agendas (Chung Wei, Darling-Hammond, \& Adamson, 2010). Teachers and administrators do not always agree on 
what professional development topics are most important. Teachers often perceive professional development as only good for earning credit toward teacher certification retention (Hiemstra \& Brockett, 1994). Online professional development opens possibilities for teacher choice of programs they consider meaningful and, at the same time, can allow flexible scheduling.

The purpose of this literature review is to provide an overview of the history and evolution of professional development and how it affected the eventual development of online professional development. Areas of discussion will include relevant learning theories, political and professional factors that influence professional development, and the criteria necessary for effective online professional development. The issues sometimes created by the gaps between influencing factors and criteria for effective online professional development will also be discussed. Understanding influencing factors, the criteria of effective professional development, and resulting gaps can, at a minimum, help guide district administrators when selecting online professional development for district staff. The information found in this literature review can also serve as a guide for professional development instructional design. Awareness of these factors may enable instructional designers to develop professional development with the factors discussed in this literature review to maximize effectiveness and reduce common issues.

\section{Methodology}

The literature review began with searches of the databases found in the University of Phoenix and Fairfield Univeristy online libraries. Keywords used included professional development, adult learning, online learning, online professional development, learning theory, educational technology, $21^{\text {st }}$ century skills, knowledge management, and educational standards. The databases used ultimately expanded to EBSCOhost, ProQuest, Gale Powersearch, the ISTE, Google Scholar, EdlTLib, and the Association for Educational Communication and Technology 
databases. Resources were stored and organized using the social bookmarking tool, DIIGO. Tags were used for organizational purposes. Organizational tag terms included: online, professional development, standards, peer-reviewed, dissertation, learning theory, and adult learning.

This literature review includes a discussion of 107 works. These works include 62 peerreviewed studies, 33 educational texts, eight doctoral dissertations, and seven government educational standards documents. The educational texts and government educational standard documents were reviewed primarily to develop the discussions of the evolution of professional development. For this literature review, educational texts were defined as any educational books or papers that are not peer-reviewed. Peer-reviewed articles were identified by the review process prescribed by the journal in which they appeared (Creswell, 2013). The evaluation of the peer-reviewed studies was used primarily as part of the discussion of the qualities of effective professional development, both traditional and online.

Selection criteria for inclusion in this literature review included (a) peer reviewed journals that addressed the definition and qualities of effective professional development, (b) research-based educational texts which addressed the same topics but were not peer-reviewed, and (c) educational texts and government educational standards documents that provided framing information about important professional development requirements and paradigms. Texts that addressed online professional development not specific to K-12 public education were excluded.

\section{Importance of Professional Development}

The National Staff Development Council (NSDC) stated that educators should commit $25 \%$ of their paid professional time to learning and collaboration (NSDC, 2001). However, the percentage of paid professional time that teachers actually devote to professional development is 
usually closer to the state minimum requirement, which is much lower than the prescribed $25 \%$ (Hill, 2009).

The guidelines for the percentage of paid professional time teachers should devote to professional development suggested by the NSDC are in place so teachers stay current on best practices in teaching. Professional development helps teachers meet the needs and goals of the district (Spanneut, Tobin, \& Ayers, 2012). Spanneut et al. (2012) researched administrators' perceptions of what professional development the teachers in their respective districts needed the most. Spanneut et al. conducted the preliminary study anonymously through a needs assessment. Spanneut et al. asked the administrators to assess their districts' needs from the perspective of the New York State Educational Leadership Policy standards. Working toward the needs and goals of the district through professional development is essential for moving toward meeting the objectives of educational reform (Desimone, 2009).

Programs that focus on continuous professional development workshops that are relevant to teacher needs may reduce teacher resentment if designed effectively (Bereiter, 2002; Garet, Porter, Desimone, Birman, \& Yoon, 2001). In a quantitative descriptive study, Garet et al. supported the research of Bereiter with a national survey of randomly chosen teachers. Although the study was broad in scope, Garet et al. risked the potential of only gathering feedback from only engaged teachers who took the time to complete the survey. However, other researchers have conducted studies that support the research of Garet et al. (Bereiter, 2002; DarlingHammond et al., 2009).

\section{Political and Professional Influences on Professional Development}

Thoughts have changed over the last 50 years about the most pressing needs in education. The changes in thought stem from efforts by the government to address shortcomings in 
American education whether those affected welcome the changes or not (Katz, 2010). The objectives of these initiatives have included everything from efforts to provide equitable education for everyone to raising the overall quality of American education. Common Core State Standards (CCSS) is one initiative resulting from the perceived shortcomings in American education.

Common Core State Standards. The National Governor's Center for Best Practices (NGA Center) and the Council of Chief State School Officers (CCSSO) created the CCSS jointly to help achieve consistency on a national level (CCSSI, 2009; Council of Chief State School Officers, 2012). The standards emphasized evidence-based higher order standards that are clear and consistent (CCSSI, 2009). Creating the standards helped to ensure the individual states and territories were operating on a level base. At the time of standards, 49 states and territories have joined the common core initiative (National Governor's Association, 2009). The states that have not adopted the CCSS are Alaska, Minnesota, Nebraska, Texas, and Virginia along with the American Samoan Islands, Northern Mariana Island, and Puerto Rico territories (CCSSI, 2012b). The NGA Center and CCSSO created the CCSS on the state level as opposed to the federal level (CCSSI, 2009). They chose state level collaboration with the intention of achieving consistency in standards across the nation (CCSSI, 2009; CCSSO, 2012; NGA, 2009). The consistency would allow educational leaders to benchmark American students against other top performing nations (NGA, 2009). NGA vice Chair Vermont Douglas supported the train of thought by asserting that American education needs "to maintain America's competitive edge, we need all of our students to be prepared and ready to compete with students from around the world" (NGA, 2009, para. 4). Not everyone in the educational field completely agrees with adopting the CCSS. 
Several educational researchers have argued that policy makers, intentionally or not, are deciding what is and is not important in education (Biesta, 2010; Cuban, 2010; Oakley, 2002).

A distinct connection exists between CCSS and twenty-first century skills (Ballard, 2010, Tucker, 2012). Cosmah and Saine (2013) stated that teachers need to understand that their "teaching practices must integrate technology to ensure students become digitally fluent" (p. 82). The CCSS requires students to "use technology, including the Internet, to produce and publish writing and to interact and collaborate with others" (CCSSI, 2012, para. 7). Students are also required to master research skills within the writing, social studies, and science common core skill sets (CCSSI, 2012). These common core strands connect directly to the information literacy, media literacy, and information and communication technology literacy twenty-first century skill strands (Trilling \& Fadel, 2012). The shift towards the CCSS, coupled with the established importance of twenty-first century skills, is making the need for relevant professional development more important than ever (Ash, 2012).

\section{Defining Professional Development}

Fishman defined professional development as "learning activities related to the profession of teaching" that occur after initial certification (2016, p. 14). Professional development can have many variations including number of participants, session or program length, design and delivery method. Any professional development delivereded through the Internet can be defined as online professional development (2016). Professional development is an ongoing scholarly process for teachers throughout their careers. Humboldt (1810) described scholarship as incomplete knowledge. Humboldt believed that scholarship is never complete, whether referring to research or teaching. Humboldt's statement is still relevant today despite being over two centuries old. The same logic can be applied to professional development. 
Professional development is an ongoing process that teachers should engage in throughout their teaching career (Fishman, 2016).

The concept of scholarship and practice are two parts of the scholarship, practice, and leadership model (Thompson, 2007). The leadership component is evident when the educator makes the transition from professional development participant to planner, designer, or deliverer of professional development as well as participant. The educator, as a leader, needs to think critically about what professional development works, and does not work, so that appropriate and effective learning experiences can be used (Burbach, Matkin, \& Fritz, 2004). Part of the process of building or selecting appropriate professional development includes understanding learning theory so the educational leader can review the design of potential professional development for effectiveness (Knowles, 1990; Meijer, Kuijpers, Boei, Vrieling, \& Geijsel, 2016; Taylor, 2011).

\section{Influence of learning theories on professional development}

Learning is defined as "knowledge or skill acquired by instruction or study" (Zemke \& Zemke, 1995, p. 32). This definition applies to a broad spectrum of learning approaches, ranging from essentialist to constructivist learning theory (Berg-Sorensen, Holtug, \& Lipper-Rasmussen, 2010). Sound education is based on sound learning theory, whether in a face-to-face or online format (Haythornthwaite \& Andrews, 2011). Professional development should be designed and delivered with the learner in mind (Arends, 2014). Best practices of instruction based on sound learning theory should be considered when choosing or designing professional development for teachers (Desimone \& Garet, 2015). Essentialist theory started with Bagley (Sadker \& Zittleman, 2006). Bagley proposed that educators spend too much time on the process of learning. Bagley argued that there should be a greater focus on teaching the content. A focus on content is not to be confused with the teaching style of direct instruction. 
Direct instruction in professional development has been described as meaningful and effective in studies by Van Kujik, Deunk, Bosker, \& Ritzema (2016). In an experimental study, students of teachers receiving direct instructional coaching on reading instruction showed a marked increase in reading skills over those in the control group. Conversely, Desimone and Pak found "little empirical evidence that coaching improves teacher practice" (2016, p.2).

Researchers who review the current best practices of teaching can trace the theoretical origins back to works of scholars such as Dewey (1938) and Vygotsky (1978). The ideologies of Dewey and Vygotsky align more closely with constructivist theory. Constructivist-style teaching allows learners to build, or construct, their knowledge rather than delivering content directly through lectures and readings like in essentialist classrooms (Berg-Sorenson et al., 2010). These scholars and their theories have direct applications to the development of effective professional development (Darling-Hammond, Chung Wei, Andree, Richardson, \& Orphanos, 2009). Many of the qualities of a constructivist learning environment are either aligned or the same as the qualities of effective online professional development that are discussed later in this literature review. Examples of these qualities include collaboration and interactivity which are important for being able to build knowledge by manipulating learning materials and resources (Arisoy, Cakiroglu, Sungur, \& Telli, 2016).

Much of the current literature identifies significant advantages to a constructivist classroom rather than an essentialist classroom (Berg-Sorenson et al., 2010). The adult learning theory, andragogy, applies the concept of constructivism to adult learners (Cox, 2015). The theory of Andragogy states that adult leaners draw from their previous experiences. In addition, readiness to learn is connected to the perceived need by the learner (2015). 
Learning experiences built on pedagogical theories have equal relevance in all learning environments, including teacher professional development. Professional development should be designed with best teaching practices in mind for optimal learning. Professional development needs to be perceived as relevant to the learners professional growth and needs. However, several studies indicated that this is not the case (Antoniou, Kyriakides, \& Creemers, 2011; Chung Wei et al., 2010). There is overlap between Andragogy learning theory and the qualities of effective professional development identified in this literature review just as there was with constructivist learning theory. This is discussed in the section on the importance of professional development.

Most research in learning theory and professional development indicates a collaborative learning environment is in the spirit of experientialism and constructivism. The argument being that professional development should focus on the participant constructing their own learning through quality experiences like collaboration rather than limiting opportunities such as lecture only formats. However, many teachers still view their professional development programs as lacking collaborative opportunities (Antoniou, Kyriakides, \& Creemers, 2011; Chung Wei et al., 2010). In a study involving a quantitative assessment of 130 teachers, Antoniou et al. (2011) found that a holistic and collaborative teaching environment had a positive impact on the academic achievement of the students of teachers who participated in the study. Research supports teacher assertions that many of the existing professional development opportunities at the time of this article have not been designed using sound learning theory based strategies like collaboration (Antoniou et al., 2011; Webster-Wright, 2009). The issue of ineffective professional development that does not incorporate sound learning theory has existed throughout the history of professional development (Meagher, 2011). The qualities of effective professional 
development are relevant to both traditional and online professional development. Online learning tools can be chosen intentionally to allow for a high level of constructivist style learning activities.

\section{Features of Effective Professional Development}

Effective professional development can affect teacher attitudes and skills positively leading to an increase in quality education (Hien, 2008). Professional development is an opportunity for teachers to collaborate and learn from peers despite spending a significant amount of their work time in a classroom separated from each other (Beavers, 2009). Organizers of professional development often focus more on earning the professional development credit required for teaching certification retention than the process of lifelong learning as a teacher (Hiemstra \& Brockett, 1994). The tendency to choose professional development for the purpose of earning professional development credit rather than based on the teachers' needs can result in resentment by the teachers for being required to participate in a program perceived as a waste of time (Bereiter, 2002; Hiemstra \& Brockett, 1994).

Much research exists on the most important features of effective professional development (Darling-Hammond et al., 2009; Lotter, Thompson, Dickenson, Smiley, Blue, \& Rea, 2016; Lutrick, 2012; Lutrick \& Szabo, 2012). Lutrick and Szabo interviewed principals about their role as instructional leaders regarding effective instructional design in a qualitative case study. Lutrick and Szabo questioned the instructional leaders about their beliefs regarding effective professional development, and analyzed study results for common themes, comparing the results to the existing research literature at the time of the study. Results indicated instructional leaders agreed that five common qualities are necessary for effective professional development to occur (Lutrick \& Szabo, 2012). According to the instructional leaders; 
professional development should be ongoing, collaborative, data driven in design, interest driven in design, and interactive.

Another qualitative case study by Lutrick (2012) yielded the same results as her collaborative research with Szabo. Lutrick and Szabo (2012) compared the results of their study with the NSDC professional development standards. The NSDC standards consist of seven components for productive professional development (NSDC, 2011). The NSDC standards included seven components that an effective professional development program should have: learning communities, leadership, resources, data, learning design, implementation, and outcomes. Lutrick and Szabo found a significant overlap between the qualities of effective professional development the instructional leaders in their study suggested and the qualities of professional development the NSDC prescribe. Lutrick and Szabo identified the overlap as evidence the instructional leaders were using the NSDC professional development standards to guide their professional development programs.

The NSDC has published several studies on professional development. Researchers designed a study to reveal the qualities of professional development that improves teachers' practice and student achievement (Darling-Hammond et al., 2009). The results of the study indicated that professional development must be ongoing, relevant to the teachers' needs, and provide opportunity for teacher collaboration. The teachers in the study found that much of their professional development experience did not meet these criteria. Most teachers found their professional development programs disjointed rather than ongoing. Only $23 \%$ of the teachers felt their professional development had relevance to their teaching. In a grounded theory study, only $16 \%$ of the teachers questioned felt that there was intentional collaboration incorporated into their professional development programs (Chung Wei et al., 2010). 
In a qualitative study, Schrum and Levin (2013) conducted a review of exemplary schools in regards to success with professional development. Five schools were part of the study. The researchers chose the districts based on the combined factor of having earned state or national professional development awards and for their high level of student and staff diversity. The results indicated that a successful professional development program should have both formal and informal opportunities, including choices for staff to select from opportunities so their needs can be better met.

The research results indicate that standards and skills should guide effective professional development (Darling-Hammond et al., 2009). Effective professional development design is interactive, collaborative, interest driven and differentiated, ongoing, designed with appropriate resources, and implemented correctly (Lutrick \& Szabo, 2012). Professional development providers should provide opportunities for participants to work with others to allow them opportunities to brainstorm and collaborate on difficult topics. Providing professional development choices provides differentiation to meet different professional growth needs and help optimize levels of interest. Providing resources for future use can also help maintain relevance and raise levels of engagement. Figure 1 shows a visual of the aspects of effective professional development. These aspects represent the criteria for effective professional development that are identified consistently throughout the literature discussed in this review. The goal of professional development is to improve student learning through improved teaching (Gagne et al., 2005). Instructional leaders should evaluate the effectiveness and success of professional development programs so they can modify future professional development accordingly for further improvements. Using the aspects of effective professional development can help guide this process. 


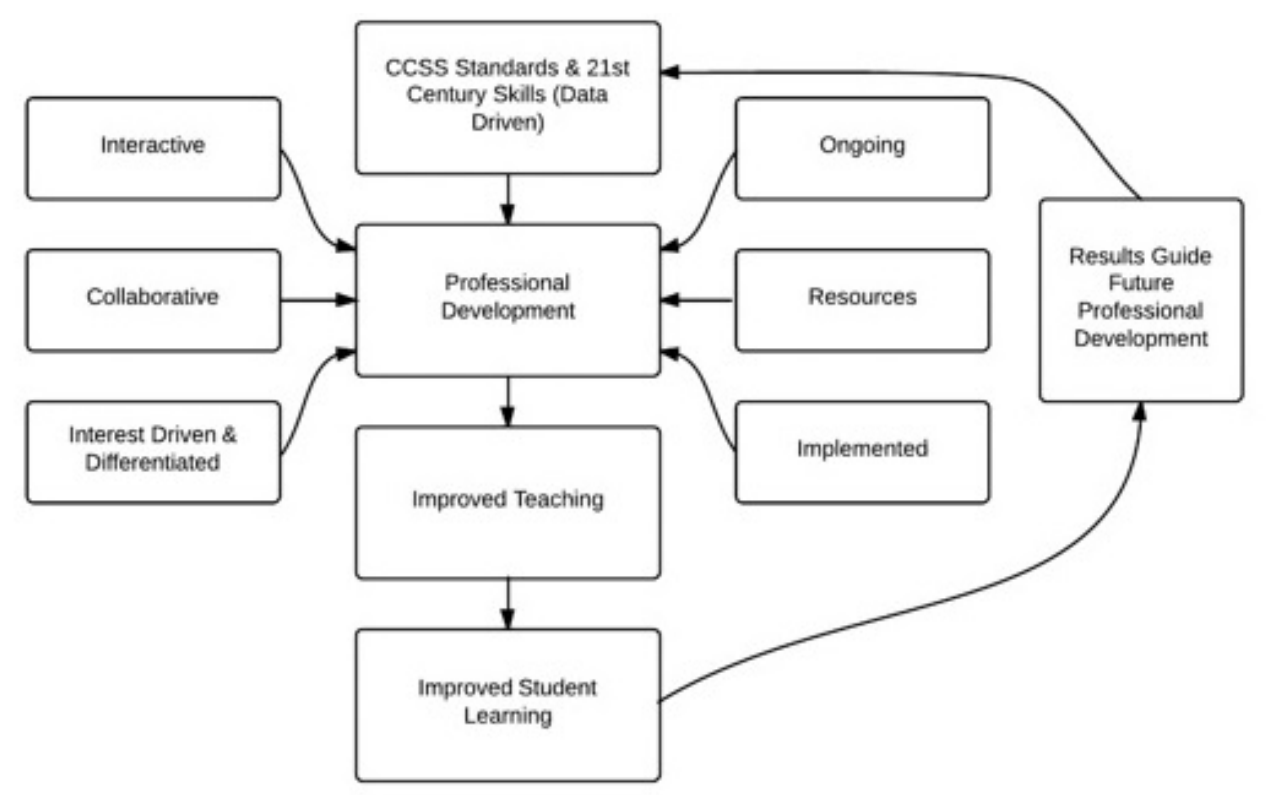

Figure 1. Graphic organizer displaying the aspects of effective professional development. Adapted from "Instructional Leaders' Beliefs about Effective Professional Development," by E. Lutrick and S. Szabo, 2012, Delta Kappa Gamma Bulletin, 78, p. 6-12. Copyright 2012 by Delta Kappa Gamma Society International.; "Teachers'technology professional development: Lessons learned from exemplary schools," by L. M. Schrumm and B. B. Levin, 2013, TechTrends, 57, p. 38-42. Copyright 2013 by TechTrends: Linking Research \& Practice to Improve Learning.

Figure 1. Graphic organizer displaying the aspects of effective professional development.

Adapted from “Instructional Leaders' Beliefs about Effective Professional Development," by E.

Lutrick and S. Szabo, 2012, Delta Kappa Gamma Bulletin, 78, pp. 6-12. Copyright 2012 by

Delta Kappa Gamma Society International; “Techers' technology professional development:

Lessons learned from exemplary schools," by L. M. Schrumm and B. B. Levin, 2013, Tech

Trends, 57, pp. 38-42. Copyright 2013 by TechTrends: Linking Research \& Practice to Improve Learning. $<$ TQ $>$ Crop caption out of figure. $</$ TQ $>$

\section{Guiding Models for Online Professional Development}

There are six identified qualities for effective professional development. Professional development should be interactive, collaborative, interest driven and differentiated, ongoing, 
provide resources, and should be implemented in day to day teaching. An additional framework to serve as a guide can be helpful for design or selection of online professional development is the Community of Inquiry Model (CoI).

The CoI model presents a "process for creating a deep and meaningful (collaborativeconstructivist) learning experience through the development of three interdependent elements (Mehta, Makani-Lim, \& Easter, 2016, p.412). The CoI model suggests three key components for any online learning experience to be effective: social presence, cognitive presence, and teaching presence (Pollard, Minor, \& Swanson, 2014).

Social presence can be described as interaction between course participants. Social presence is often identified as a key quality to be incorporated into online learning experiences since it is not something that always occurs naturally in an online environment (Richardson, Swan, Lowenthal, \& Ice, 2016). A social presence can be beneficial for establishing a collaborative and interactive learning environment. This is achieved by helping students feel more involved and connected (Lowenthal \& Dunlap, 2014). A social presence can be established in a course via synchronous and asynchronous means, including video conferencing and discussion threads (2014).

Cognitive presence refers to how learners interact with the content in an online learning environment (Dunlap, Verma, \& Johnson, 2016). Cognitive presence is supported by a strong social and teaching presence (Lowenthal \& Dunlap, 2014). For example, the level of cognitive presence can be impacted by what resources are chosen for use in a course by the course designer or instructor. Resources are often chosen during the design of a course or when an instructor is preparing to teach the course. Designing and delivering a course is part of establishing a strong teaching presence (Richardson et al., 2016). Teaching presence refers to 
the design and delivery of an online course (Dunlap et al., 2016). A high quality educational experience can be established by combining all three of these factors effectively (Dunlap et al., 2016). Figure 2 shows a visual representation of the CoI model.

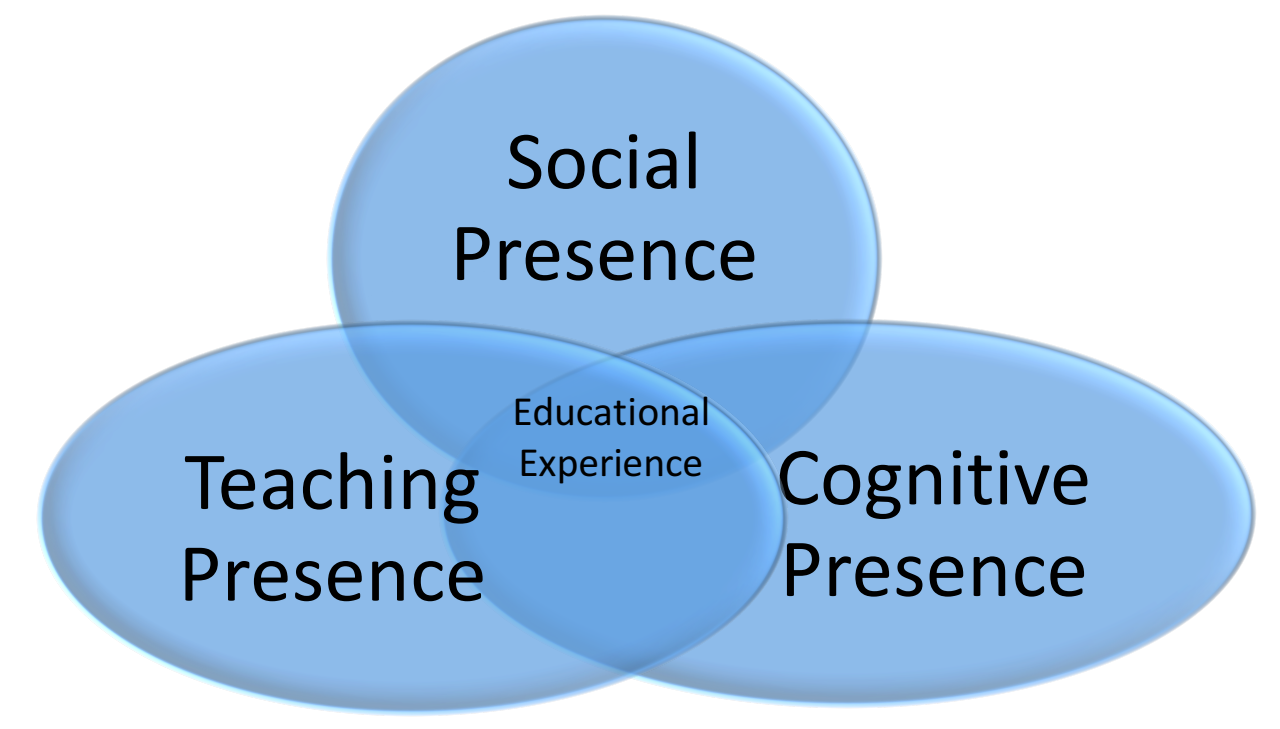

Figure 2. The Community of Inquiry (CoI) model

There are several points of overlap between the identified qualities of effective professional development and the CoI model. Establishing the three presence components can help establish or strengthen some of the qualities named earlier including interactivity, collaboration, and resources. Properly establishing a strong teaching and cognitive presence can also assist with another quality, differentiation. The qualities of ongoing and implemented remain, but those could be described as more systemic in nature.

\section{Online Professional Development}

Online learning is an option for professional development with much potential (Cornelius \& Macdonald, 2008; Yoder, 2001). Online learning is also an option that can instill 
apprehension and fear in those who have little or no experience with online courses (Dunst \& Raab, 2010; Yoder, 2001). Someone new to online learning may not know what to expect, or they may have encountered a poorly designed online learning program previously. A poor learning experience could have a more negative impact than no experience. The online professional development format presents both formal and informal professional learning opportunities if teachers and districts can overcome apprehensions. The operational definition for online professional development is any Internet-based form of learning or professional growth process that an educator can engage in. Professional development must be done in an effort to improve the aspects of a teacher's job performance. Aspects can include content, skills, or pedagogical abilities. Online professional development is a delivery method option.

\section{Instructional design}

Instructional designers can build online professional development within the district, or the district instructional leaders can outsource to an external source that specializes in online professional development (Dunst \& Raab, 2010; Little \& Housand, 2011; Muñoz, Guskey, \& Aberli, 2009). In a quantitative descriptive study of 225 teachers from 26 states, Dunst and Raab collected self-evaluations from participants regarding the effectiveness of either short 1 to 2 day workshops or weeklong intensive workshops. A statistically significant percentage of the group found both types of outsourced professional development programs effective, particularly the weeklong intensives (Dunst \& Raab, 2010). However, Dunst and Raab did not compare the results to professional developments developed within the teachers' districts to provide a point of comparison.

Teacher learning in a professional development program is maximized when the program has been designed based on instructional design that incorporates best practice twenty-first 
century skills. Such professional development is rooted in educational theory and best teaching practices (Gustafson \& Branch, 2007). Ideally, instructional leaders would build online professional development in district. However, in-district building of professional development may not always be an option. Sometimes, professional development may need to be outsourced (Dunst \& Raab, 2010). Either way, administrators and instructional design experts need to use effective instructional design practice to maximize teacher learning.

\section{Potential of online professional development}

Geographic boundaries are not a limiting factor with online professional development because online learning is Internet-based. Online learning opens up opportunities for collaboration across districts regardless of distance. Gaumer et al. (2012) conducted a study that supported increased opportunities. The mixed method study was comprised of 149 participants. Eighty-six participants were from rural communities while 63 were from non-rural communities. Gaumer et al. designed the study to "examine the effect of asynchronous online professional development in rural and non-rural settings" (p. 22). The results indicated the educators from the rural communities felt that online professional development provided collaborative efforts with other special educators the district could not otherwise provide. Districts may have limited resources resulting from geographic remoteness or lack of funding (Johnson \& Strange, 2009; Lindahl, 2011). The study delivered promising results regarding using online professional development. However, the study design focused on rural and non-rural professional development that may not apply to other district environments.

Little and Housand (2011) found similar results to Gaumer et al. (2012) in their study of the advantages of online professional development for teachers of gifted students. Teachers of gifted students also have difficulty finding other teachers of gifted students to collaborate with 
(Little \& Housand, 2011). Online professional development helped alleviate the problem.

Several researchers have cited the ability to collaborate with other professionals who are too far away for reasonable face-to-face interaction as one of the key advantages of online professional development on an international level (Coughlin \& Kajder, 2009; Kamarul Kabilan et al., 2011). In a quantitative quasi-experimental study, Coughlin and Kajder found a $72 \%$ achievement improvement in the students of teachers who participated in online professional development with a strong collaborative component. The control group in the study showed only a 5\% improvement in achievement (Coughlin \& Kajder, 2009). A review of the work and reflective statements of 142 Malaysian teachers who collaborated to produce newsletters in small online groups of three to four showed the importance of "sharing and exchanging, and socializing" (Kamarul Kabilan et al., 2011, p. 94).

Online professional development can be either formal or informal. Examples of informal online professional development are personal learning networks (PLNs) or professional learning communities (PLCs) (Cox, 2010). Personal learning networks and PLCs are resources for teachers to stay current on various professional topics. However, informal professional development can have little structure. Little structure results in increased probability of poor results (Servage, 2009). Formal professional development links directly to educational standards resulting in more structure (Lutrick \& Szabo, 2012). Competent educators use current standards in the instructional design process of formal professional development (Fabry, 2009a). The outcome is more favorable results regarding having a positive impact on teaching performance.

Online learning allows options for selection of learning tools. One example is the learning setting can be synchronous or asynchronous. Examples of synchronous learning include webcasts, chat rooms, and audio-visual technology. Examples of asynchronous learning include 
e-mail, threaded forums, and news groups (U.S. Department of Education, 2010). A common theme across these tools is they each enable social interactions among the users. Holmes, Signer, \& MacLeod (2010) found that both social interaction and teacher presence had a significant positive relationship among 95 urban K-12 private school teachers enrolled in online professional development. When asked an open-ended question about the impact the professional development had on their teaching, $95 \%$ of the teachers who responded stated there was a direct impact. One limitation of the mixed-method correlational study related to the process of participant selection. The participants had to have completed an online professional development within a year previous of the study (Holmes et al., 2010). Desimone (2009) asserted that research would be more robust if there were variations in the elapsed time since the participant's last online professional development completion. Desimone (2009) suggested variation so the retention of the material and skills could be ascertained more accurately.

Just as Holmes et al. (2010) found social interaction to be a significant factor in online professional development, other important interaction components are found in effective online professional development. Studies designed to examine the key components of effective online professional development identify three primary types of interaction. These three types of interactions are student to teacher, student to student, and student to content (Annetta, Cheng, \& Holmes, 2010; Aranda, 2011; Bradley, 2011; Nandi, Hamilton, \& Harland, 2012).

\section{Limitations found in online professional development}

Just as online professional development presents opportunities, several perceived deficiencies exist in most professional development programs (Chung Wei et al., 2010; DarlingHammond et al., 2009). Many professional development programs lack the commonly accepted qualities that are essential for creating effective professional development (Chung Wei et al., 
2010; Darling-Hammond et al., 2009). Properly designed professional development should be interactive, collaborative, interest-driven and differentiated, ongoing, consisting of the proper resources, and properly implemented (Lutrick, 2012; Lutrick \& Szabo, 2012; NSDC, 2011). Instructional leaders who choose or instructional designers who design online professional development without these features risk significantly reduced results (Lutrick \& Szabo, 2012). Online professional development that does have all the mentioned features does not produce automatic results (Dash, Magidin de Kramer, O'Dwyer, Masters, \& Russell, 2012). Dash et al. (2012) surveyed 92 fifth grade mathematics teachers who participated in online professional development modules. Analysis of the results of the quantitative correlational study indicated that an increase in teacher outcomes did result in increased results in the students of the participating teachers in the study to a significant degree. However, online professional development does "offer one promising direction for providing increased professional learning opportunities across a range of topics and initiatives as well as for promoting professional collaboration and teacher facility with technology resource” (Little \& Housand, 2011, p. 19).

Modes of delivery. Little and Housand (2011) suggested five modes of delivery for online professional development. The five modes are (a) accessible websites or online resources, (b) technology for interacting with face-to-face audiences in real time, (c) professional development supported with asynchronous online discussion, (d) video conferencing, and (e) the construction and facilitation of an ongoing online community.

Mode 1. The first mode of online professional development is accessible websites or online resources. The way knowledge "is produced, stored, and distributed" (p. 26) has changed because of changes in technology (Pirmoradi, Allahyari, \& Soluki, 2011). This organization of information is knowledge management (McBride, 2011). Educators can access information 
through the Internet easily instead of having to go to a library. Information on any topic is accessible from any device with Internet capability including mobile phones (Hong-Ren \& HuiLing, 2010). However, accessible information does not indicate credible or reliable information (McBride, 2011). The ability to find and evaluate information for use is a twenty-first century skill called information literacy. Being able to evaluate online resources for validity and reliability is important (Trilling \& Fadel, 2012).

Accessible websites and online resources are useful tools for educators who are looking for a resource to help them (Pirmoradi et al., 2011). However, knowledge management resources lack the collaborative and interactive components of well-designed and effective online professional development (Chung-Wei et al., 2010; Darling-Hammond et al., 2009; Lutrick \& Szabo, 2012). Self-paced formal tutorial programs are a potential online resource that may have an interactive component (Mazoue, 2013). Self-paced formal tutorials are found in the form of massive open online courses (MOOC's). Learners interact with the programs and technology in MOOC's as part of the learning process. The learning can be interactive in the form of student to content. However, students participate in MOOC's as individuals. Students can ask their peers questions in a discussion forum or solicit feedback from the instructor. However, no formal interaction occurs with other learners or with an instructor.

Mode 2. The second mode of online professional development is technology for face-toface interaction with audiences in real time (Little \& Housand, 2011). The second mode of professional development does not fit the strict definition of online professional development (Arano-Ocuaman, 2010). Technology for face-to-face interaction with audiences in real times fits the definition of a technology enriched learning environment rather than a blended learning environment (Caulfield, 2011; Rose \& Smith, 2010). Blended learning is any type of learning 
that falls along the continuum between online and face-to-face learning (Rose \& Smith, 2010). A technology enriched learning environment is a face-to-face situation that has a strong technology presence (Horn \& Staker, 2014). Therefore, educational researchers cannot directly compare a technology enriched professional development situation to a strict online professional development.

Mode 3. The third mode of online professional development is professional development supported by asynchronous online discussion (Little \& Housand, 2011). Mode 3 may be blended or strictly online in format depending on the design. Whether the initial professional development portion is online or face-to-face in format, it is followed by online asynchronous discussion so the learning experience may continue and possibly become a richer experience for the participants (Cheung \& Hew, 2010; Cook, Dickerson, Annetta, \& Minogue, 2011; Vitale, 2010). Cheung and Hew (2010) observed 40 online forums in a quantitative correlational study. The analysis of the results revealed a significant positive correlation between more participants and an increase in higher-level knowledge construction (Cheung \& Hew, 2010). Cook et al. concluded the same in a pre-test and post-test quantitative study. In the study, a statistically significant percentage of the group found an asynchronous discussion component beneficial to a professional development program (Cook et al., 2011).

Several options exist regarding asynchronous discussion resources. Options include blogs, groups, social networks, wikis, and other cloud-based collaboration tools like Google Docs (Little \& Housand, 2011; Prensky, 2010; Richardson, 2010). An asynchronous discussion tool allows users to have a conversation at anytime from anywhere (Cheung \& Hew, 2010).

Professional development supported by asynchronous discussion does meet several of the criteria for effective professional development (Chung-Wei et al., 2010; Darling-Hammond et 
al., 2009; Lutrick \& Szabo, 2012). Asynchronous discussions are interactive and collaborative by design; they are also interest driven and differentiated as long as the participants choose to continue with the program. As long as the participants maintain that interest, the asynchronous discussion is also ongoing. As with any discussion, the participants can share resources. The ability to share resources can also make the asynchronous discussion useful as knowledge management tool.

Mode 4. The fourth mode of online professional development delivery is videoconferencing (Little \& Housand, 2011). The technology used for videoconferencing can include webinar software, including Skype, Zoom, and Google Hangouts, along with several other options (Prensky, 2010). Many videoconferencing resources are capable of recording the conference for later access (Rush, Walsh, Guy, \& Wharrad, 2011). However, instructional designers normally design videoconferencing professional development workshops as single units of instruction (Rush et al., 2011). Therefore, they do not have the ongoing quality needed to fit the definition of effective professional development (Chung-Wei et al., 2010; DarlingHammond et al., 2009; Lutrick \& Szabo, 2012).

Mode 5. The fifth mode of professional development is constructing and facilitating an ongoing online community (Little \& Housand, 2011). Mode 5 of professional development is seen in social network formats like Twitter, Ning, or Facebook. A successful online community is interactive, ongoing, and interest driven as seen in effective professional development. Mode 5 professional development situations are often known as personal learning networks. They allow for a high level of constructivist style learning due to the high level of personalization. However, the online community form of professional development is not always standards driven (Davis, 2011). 
Course management system. Sometimes instructional designers use multiple modes in an online professional development program. Course management systems are a collection of online learning tools contained in one system (Adams, 2010; Holmes et al., 2010). Learning management system is another term for course management system (Badawood, 2011; Unal \& Unal, 2011). Common examples of course management systems are MOODLE and Blackboard (Payette \& Gupta, 2009). Multiple instances of professional development are offered through course management systems (Adams, 2010; Holmes et al., 2010; Oliver, Kellogg, Townsend, \& Brady, 2010; Thomas, 2010).

Course management system designers build the programs for maximum tool compatibility so that users may use the tools in conjunction with each other or independently (Tella, 2011). In a quantitative descriptive study, Tella (2011) administered a survey to 503 students in Botswana to create a scale to measure the success of other course management systems.

Research indicates that course management systems are effective for those familiar with technology, but that user satisfaction diminishes as user familiarity with the technology declines (Taylor, 2011; Tella, 2011; Thomas, 2010). Taylor (2011) used a qualitative social constructivist case study research method to study the use of course management systems for professional development. Taylor chose the social constructivist method to study the interactive component needed for effective professional development. The choice of a qualitative study was to enable the development of a holistic picture of the collected data (Taylor, 2011). Thomas (2010) reached the same conclusion when interviewing online professional development participants and instructors. Both online professional development participants and instructors stated that 
their satisfaction and comfort level with online professional development increased as they gained experience with the program.

Bereiter (2002) and Garet et al. (2001) stated that effectively designed online professional development programs provide a rich learning experience that teachers can fit into their already hectic work schedule. However, a common misconception is that experts can develop online professional development by transferring a conventional face-to-face professional development into an electronic format (Fabry, 2009b). The perception is unrealistic. The dynamics of the online professional development environment differ from the conventional face-to-face environment (Fabry, 2009a; Fabry, 2009b; Kranch, 2008; Simms \& Knowlton, 2008). Online professional development workshops should ideally be built from the ground up to be effective (Fabry, 2009a; Fabry, 2009b; Gagne et al., 2005; Kranch, 2008). Competent instructional design requires an intentional instructional unit design that takes the different content delivery medium into consideration (Gagne et al., 2005). Evaluation must then occur during and after the instructional unit, so appropriate modifications can be implemented (Gagne et al., 2005; Gustafson \& Branch, 2007).

The most common instructional design models use some variation of the ADDIE model (Hardre, 2013). The components of the ADDIE model are analyze, design, develop, implement, and evaluate (Gagne et al., 2005). Instructional design theorists have asserted that some variation of each of these steps is important for effective instructional design (Aden, 2010; Fabry, 2009a; Fabry, 2009b; Gagne et al., 2005; Kranch, 2008).

\section{Implications}

Each of the five modes has at least some of the qualities of effective online professional development. However, none of them show evidence of all six qualities to a significant degree. 
The same can be said for the three aspects of the CoI model; social presence, cognitive presence, and teaching presence. It may be an unrealistic expectation to be able to consistently offer online professional development that has all six stated qualities. This does not preclude district leaders from offering any of these delivery modes as resources for teachers to access. However, the qualities of effective online professional development should be, at least, considered when choosing online professional development. Instructional designers should consider incorporating the qualities when designing online professional development. The following questions should be considered for each quality.

Interactive. Does the online professional development offering have some level of interactivity? Are there tools available for synchronous discussions like chat rooms or video conferencing? Are there tools available for asynchronous discussions like forums? Do any of these resources allow for fostering a social presence in the program? Is social media used in any way?

Collaborative. Collaboration is different from interactivity. Does program design allow for people to work together or just at the same time as each other? Does the design allow participants to build their own personal understandings in the spirit of constructivist learning?

Interest Driven \& Differentiated. Is the professional development offering a one size fits all design or does it provide opportunities for learners to make choices that may reflect their personal learning preferences or interests? Opportunities for choices could include content, delivery, or teaching strategies. Are the teachers interested in what is being taught or do they see it as valuable for their professional growth? 
Ongoing. What does the program being considered or designed hold for the future? Are there future learning opportunities offered that build on what is being taught? Is there a support system in place for participants who may have questions after the program has ended?

Resources. What resources are provided to teachers who participate in the online professional development? Are there professionals available to consult with? Is there a discussion forum so participants can share ideas with each other? Is there a databank so colleagues can share resources and tools?

Implemented. What is the long-term expectation in the district or school for what is being taught? Is this going to be a mandated initiative? Do the teachers see any value in what is being taught so they want to use it in their own teaching?

\section{Summary}

Professional development has gone through many evolutions since its beginnings. Research now exists about what qualities constitute effective professional development. This is true for both traditional and online professional development. Instructional designers should actively incorporate these qualities into their professional development programs. Online learning has several applications. Online learning exists in the corporate and military arenas, as well as the field of education. Educators use online education for both student and professional education. Online professional development is an attractive option because it can transcend geographic and time constraints depending on its design and features (Adams, 2010). Bypassing geographic and time constraints allows online professional development offerings to meet the needs of a broader audience than traditional development.

Any format of effective professional development should be standards-driven and meet the needs of the teachers to maximize student learning. Effective professional development 
should be interactive, collaborative, interest driven and differentiated, ongoing, built with available and relevant resources, and properly implemented for optimal results (Chung-Wei et al., 2010; Darling-Hammond et al., 2009; Lutrick \& Szabo, 2012). A large body of research exists indicating significant disdain for professional development on the part of teachers. Research indicates that the primary reason for this disdain is due to perceived shortcomings in the defined features of effective professional development, both traditional and online (Antoniou, Kyriakides, \& Creemers, 2011; Chung Wei et al., 2010; Darling-Hammond et al., 2009). Instructional leaders need to design or select professional development programs with the qualities of effective professional development in mind to maximize the results in teacher learning and the meeting of standards.

The same criteria apply to online professional development. Ideally, instructional leaders will build professional development in district directly to the district's need as well as be jobembedded (An Act Concerning Education, 2012). Customized online professional development may not always be an option. However, instructional leaders should build online professional development from the ground up rather than transfer an existing face-to-face program to an electronic format either way (Gagne et al., 2005).

Author Note

Joshua C. Elliott, Ed.D., is Assistant Professor of the Practice and Program Director of Educational Technology at Fairfield University in Fairfield, CT. He earned his doctorate in educational technology from University of Phoenix. Dr. Elliott runs frequent professional development workshops addressing the effective integration of technology in the classroom. He 
has also presented at conferences on the state and national level. Please address correspondence to Joshua C. Elliott.E-mail: jelliott@fairfield.edu

\section{References}

Adams, R. D. (2010). A case study of professional development in an online environment: The experiences of a group of elementary teachers (Doctoral dissertation). Retrieved from ProQuest Dissertations and Theses database. (AAT 3441264)

Aden, L. A. P. (2010). Effects of learning styles on online professional development with educators. (Doctoral dissertation). Retrieved from ProQuest Dissertations and Theses database. (AAT 3404558)

An Act Concerning Education, 12 S. $\S 39$ (2012).

Annetta, L. A., Cheng, M. T., \& Holmes, S. (2010). Assessing twenty-first century skills through a teacher created video game for high school biology students. Research in Science \& Technological Education, 28(2), 101-114. doi:10.1080/02635141003748358

Antoniou, P., Kyriakides, L., \& Creemers, B. (2011). Investigating the effectiveness of a dynamic integrated approach to teacher professional development. CEPS Journal: Center for Educational Policy Studies Journal, 1(1), 13-41. Retrieved from http://www.pedocs.de/

Aranda, A. D. (2011). Moodle for distance education. Distance Learning, 8(2), 25-28. Retrieved from http://www.infoagepub.com

Arano-Ocuaman, J. A. (2010). Differences in student knowledge and perception of learning experiences among non-traditional students in blended and face-to-face classroom 
delivery (Doctoral dissertation). Retrieved from ProQuest Dissertations and Theses database. (AAT 3432383)

Arends, R. (2014). Learning to teach. McGraw-Hill Higher Education: New York, NY.

Arisoy, N., Cakiroglu, J., Sungur, S., \& Telli, S. (2016). Analyzing middle school students' perceptions of their science classroom in relation to attitudes and motivation. Teachers Creating Context-Based Learning Environments in Science (pp. 173-190). SensePublishers.

Ash, K. (2012). Common core raises pd opportunities, questions. Education Week, 2(5). Retrieved from http://www.edweek.org

Badawood, A. M. (2011). A systematic approach to faculty development toward improved capability in tertiary teaching in a blended learning environment (Doctoral dissertation). Retrieved from ProQuest Dissertations and Theses database. (AAT 3498568)

Ballard, S. (2010). Opportunity knocks or the wolf is at the door: ICT standards and the common core. Teacher Librarian, 38(2), 69-71. doi:10.3102/0013189X11410055

Beavers, A. (2009, November). Teachers as learners: Implications of adult education for professional development. Journal of College Teaching \& Learning, 6(7), 25-30. Retrieved from http://cluteinstitute-onlinejournals.com

Bereiter, C. (2002). Education and mind in the knowledge age. Mahwah, NJ: Erlbaum. Berg-Sorensen, A., Holtug, N., \& Lipper-Rasmussen, K. (2010). Essentialism vs. constructivism: Introduction. Distinktion: Scandinavian Journal of Social Theory, 11(1), 39-45. Retrieved from http:/www.tandfonline.com/toc/rdis20/current\#.U6BVYoldVjs 
Biesta, G. J. (2010). Why “what works” still won’t work: From evidence-based education to value-based education. Studies in Philosophy and Education, 29, 491-503. doi:10.1007/s11217-010-9191-X

Bradley, W. E. (2011). A conceptual framework for the design and evaluation of online learning modules in professional training and academic education in business. The Business Review, Cambridge, 18(1), 20-27.

Burbach, M. E., Matkin, G. S., \& Fritz, S. M. (2004, September). Teaching critical thinking in an introductory leadership course utilizing active learning strategies: A confirmatory study. College Student Journal, 38(3), 482-493. Retrieved from http://www.projectinnovation.com/College_Student_Journal.html

Caulfield, J. (2011). How to design and teach a hybrid course: Achieving student-centered learning through blended classroom, online and experiential activities. Sterling, VA: Stylus Publishing.

Cheung, W. S., \& Hew, K. F. (2010, March 14). Higher-level knowledge construction in asynchronous online discussions: An analysis of group size, duration of online discussion, and student facilitation techniques. Instructional Science, 39(3), 303-319. doi:10.1007/s11251-010-9129-2

Chung, H., \& Kim, H. (2010). Implementing professional standards in teacher preparation programs in the united states: Preservice teachers' understanding of teaching standards. KEDI Journal of Educational Policy, 7(2). Retrieved from http://eng.kedi.re.kr

Chung Wei, R., Darling-Hammond, L., \& Adamson, F. (2010). Professional learning in the United States: Trends and challenges (Technical Report). Retrieved from http://learningforward.org/docs/pdf/nsdcstudytechnicalreport2010.pdf?sfvrsn=0 
Cook, M., Dickerson, D. L., Annetta, L. A., \& Minogue, J. (2011). In-service teachers’ perceptions of online learning environments. Quarterly Review of Distance Education, 12(2), 73-79. Retrieved from http://www.infoagepub.com/index.php?id=89\&i=58

Cornelius, S., \& Macdonald, J. (2008). Online informal professional development for distance tutors: Experiences from The Open University in Scotland. Open Learning, 23(1), 43-55. doi:10.1080/02680510701815319

Cosmah, M., \& Saine, P. (2013). Targeting digital technologies in Common Core Standards: A framework for professional development. New England Reading Association Journal, 48(2), 81-86. Retrieved from http://www.questia.com/library/p62147/new-englandreading-association-journal

Coughlin, E., \& Kajder, S. (2009). The impact of online collaborative learning on educators and classroom practices. Los Angeles, CA: Cisco Systems Inc. Retrieved from http://www.cisco.com

Council of Chief State School Officers. (2012). The common core state standards initiative (CCSSI). Retrieved from http://www.ccsso.org

Cox, E. (2010). Building a future ready personal learning network. School Library Monthly, 27(3), 34-35. Retrieved from http://www.schoollibrarymonthly.com/

Cox, E. (2015). Coaching and adult learning: Theory and practice. New Directions For Adult \& Continuing Education, 2015(148), 27-38. doi:10.1002/ace.20149

Creswell, J. W. (2013). Research design: Qualitative, quantitative, and mixed methods approaches. Sage publications. 
Cuban, L. (2010, July 25). Common core standards: Hardly an evidence-based policy [Blog post]. Retrieved from http:// larrycuban.wordpress.com/2010/07/25/commoncorestandards- hardly-an-evidence-based-policy/

Darling-Hammond, L., Chung Wei, R., Andree, A., Richardson, N., \& Orphanos, S. (2009). Professional learning in the learning profession: A status report on teacher development in the United States and abroad (Research report). Retrieved from http://www.learningforward.org

Dash, S., Magidin de Kramer, R., O'Dwyer, L. M., Masters, J., \& Russell, M. (2012). Impact of online professional development on teacher quality and student achievement in fifth grade mathematics. Journal of Research on Technology in Education, 45(1), 1-26. Retrieved from https://www.iste.org/learn/publications/journals/jrte

Davis, M. R. (2011). Social media feeds freewheeling professional development. Education Week, 31(9), 13-13, 14. doi:10.1177/0961000613477122

Desimone, L. M. (2009). Improving impact studies of teachers' professional development: Toward better conceptualization and measures. Educational Researcher, 38(181), 181199. doi:10.3102/0013189X08331140.

Desimone, L. M., \& Garet, M. S. (2015). Best practices in teachers' professional development in the United States. Psychology, Society and Education, 7(3), 252-263.

Desimone, L. M., \& Pak, K. (2016). Instructional coaching as high-quality professional development. Theory Into Practice, 1-10.

Dewey, J. (1938). Experience and education. New York, NY: Touchstone. 
Ducharme, E. R., Ducharme, M. K., \& Dunkin, M. J. (2002). Teacher education. In J. W. Guthrie (Ed.), Encyclopedia of education (2nd ed., Vol. 7, pp. 2438-2448). New York, NY: Macmillan Reference USA.

Dunlap, J. C., Verma, G., \& Johnson, H. L. (2016). Presence + experience: A framework for the purposeful design of presence in online courses. TechTrends, 60(2), 145-151.

Dunst, C. J., \& Raab, M. (2010). Practitioners' self-evaluations of contrasting types of professional development. Journal of Early Intervention, 32(4), 239-254. doi: $10.1177 / 1053815110384702$

Fabry, D. L. (2009a). Designing online and on-ground courses to ensure comparability and consistency in meeting learning outcomes. The Quarterly Review of Distance Education, 10(3), 253-261. Retrieved from http://www.infoagepub.com/quarterly-review-ofdistance-education.html

Fabry, D. L. (2009b). Designing learning experiences for comparability across delivery methods. Journal of Research in Innovative Teaching, 2(1), 69-79. Retrieved from http://www.nu.edu/OurPrograms/ResearchCouncil/The-Journal-of-Research-inInnovative-Teaching.html

Fishman, B. (2016). Possible futures for online teacher professional development. In C. Dede, A. Eisenkraft, K. Frumin, A. Hartley (Eds.), Teacher learning in the digital age: Online professional developmentin STEM education. (pp. 13-30). Cambridge, MA; Harvard University Press.

Gagne, R. M., Wager, W. W., Golas, K. C., \& Keller, J. M. (2005). Principles of instructional design. Belmont, CA: Thompson. 
Garet, M. S., Porter, A. C., Desimone, L., Birman, B. F., \& Yoon, K. S. (2001). What makes professional development effective? Results from a national sample of teachers. American Educational Research Journal, 38(4), 915-915. doi:10.3102/0002831207308221

Gustafson, K. L., \& Branch, R. M. (2007). What is instructional design? In R. A. Reiser, \& J. V. Dempsey (Eds.), Trends and Issues in Instructional Design and Technology (pp. 10-16). Upper Saddle River, NJ: Pearson Education.

Hardre, P. L. (2013). What is "real world" ID anyway?. TechTrends. 57(1), 31-37. Retrieved from http://link.springer.com/journal/11528

Haythornthwaite, C., \& Andrews, R. (2011). E-learning theory and practice. Thousand Oaks, CA. Sage Publishing.

Hiemstra, R., \& Brockett, R. G. (1994). Overcoming resistance to self-direction in adult learning. New Directions for Adult and Continuing Education, 64, 32-47. Retrieved from http://onlinelibrary.wiley.com/journal/10.1002/(ISSN)1536-0717

Hien, T. (2008). Towards an effective teachers professional development in DFLSP. Connexions. Retrieved from http://cnx.org/content/m28730/1.1/

Hill, H. C. (2009). Fixing teacher professional development. Phi Delta Kappan, 90(7), 470. Retrieved from http://www.kappanmagazine.org/

Holmes, A., Signer, B., \& MacLeod, A. (2010). Professional development at a distance: A mixed-method study exploring in-service teachers' views on presence online. Journal of Digital Learning in Teacher Education, 2(27), 76-85. Retrieved from https://www.iste.org/store/product?ID=26 
Hong-Ren, C., \& Hui-Ling, H. (2010). User acceptance of mobile knowledge management learning system: Design and analysis. Journal of Educational Technology \& Society, 13(3), 70-77. Retrieved from http://www.ifets.info/

Horn, M.B. \& Staker, H. (2014). Blended: Using disruptive innovation to improve schools. Jossey-Bass: Indianapolis, IN.

Humboldt, W. V. (1810). Über die innere und äussere organisation der höherenwissenschaftlichen Anstalten in Berlin. Retrieved from http://edoc.huberlin.de/miscellanies/g-texte-30372/229/PDF/229.pdf

Johnson, J., \& Strange, M. (2009). Why rural matters 2009: State and regional challenges and opportunities. Retrieved from http://www.ruraledu.org/articles.php?id=2312

Kamarul Kabilan, M., Wan Fara, W. A., \& Mohamed, A. E. (2011). Online collaboration of English language teachers for meaningful professional development experiences. English Teaching, 10(4), 94-115. doi:10.1080/09650791003741822

Knowles, M. (1990). The adult learner: The neglected species (4th ed.). Houston, TX: Gulf Publishing Company.

Kranch, D. A. (2008). Getting it right gradually: An iterative method for online instruction development. The Quarterly Review of Distance Education, 9(1), 29-34.

Lindahl, R. A. (2011). The state of education in Alabama's k-12 rural public schools. The Rural Educator, 32(2), 1-12. Retrieved from http://www.eric.ed.gov

Little, C. A., \& Housand, B. C. (2011). Avenues to professional learning online: Technology tips and tools for professional development in gifted education. Gifted Child Today, 34(4), 18-27. doi:10.1177/1076217511427510 
Lotter, C. R., Thompson, S., Dickenson, T. S., Smiley, W. F., Blue, G., \& Rea, M. (2016). The Impact of a Practice-Teaching Professional Development Model on Teachers' Inquiry Instruction and Inquiry Efficacy Beliefs. International Journal of Science and Mathematics Education, 1-19.

Lowenthal, P. R., \& Dunlap, J. C. (2014). Problems measuring social presence in a community of inquiry. E-Learning and Digital Media, 11(1), 20-31.

Lutrick, E. (2012). The beliefs of administrators: What makes professional development effective? (Doctoral dissertation). Retrieved from ProQuest Dissertations and Theses database. (AAT 3548530)

Lutrick, E., \& Szabo, S. (2012). Instructional leaders' beliefs about effective professional development. Delta Kappa Gamma Bulletin, 78(3), 6-12. Retrieved from http://www.questia.com/

Mazoue, J. (2013, January 8). The MOOC model: Challenging traditional education. Educausereview Online. Retrieved from http://www.educause.edu

McBride, M. F. (2011). Reconsidering information literacy in the $21^{\text {st }}$ century: The redesign of an information literacy class. Journal of Educational Technology Systems, 40(3), 287300. Retrieved from http://www.baywood.com/journals/PreviewJournals.asp?Id=00472395

Meagher, T. (2011). An investigation of the relationships of teacher professional development, teacher job satisfaction, and teacher working conditions. (Doctoral dissertation). Retrieved from ProQuest Dissertations and Theses database. (AAT 3456080) 
Mehta, R., Makani-Lim, B., \& Easter, M. K. (2016). Creating online spaces for emerging markets: Investigating the link between course design and student engagement. ASBBS Proceedings, 23(1), 412.

Meijer, M. J., Kuijpers, M., Boei, F., Vrieling, E., \& Geijsel, F. (2016). Professional development of teacher-educators towards transformative learning. Professional Development in Education, 1-22.

Muñoz, M.,A., Guskey, T. R., \& Aberli, J. R. (2009). Struggling readers in urban high schools: Evaluating the impact of professional development in literacy. Planning and Changing, 40(1), 61-85. Retrieved from http://planningandchanging.illinoisstate.edu/

Nandi, D., Hamilton, M., \& Harland, J. (2012). Evaluating the quality of interaction in asynchronous discussion forums in fully online courses. Distance Education, 33(1), 5-30. doi: $10.1080 / 01587919.2012 .667957$

National Governor's Association. (2009). Forty-nine states and territories join common core standards initiative. Retrieved from http://extranet.das.pac.dodea.edu/principal/Professional\%20Articles/Standards/Common \%20Core\%20State\%20Standards\%20Initiative\%20Toolkit.pdf

National Staff Development Council. (NSDC). (2001). E-learning for educators: Implementing the standards for staff development (Educational Report). Retrieved from http://www.nsdc.org/library/authors/elearning.pdf

No Child Left Behind of 2001, S. Res. 107-110, 107th Cong., 147 U.S. Congress (2002) (enacted).

Oakley, A. (2002). Social science and evidence-based everything: The case of education. Educational Review, 54, 277-286. Retrieved from http://www.cebma.org 
Oliver, K., Kellogg, S., Townsend, L., \& Brady, K. (2010). Needs of elementary and middle school teachers developing online courses for a virtual school. Distance Education, 31(1), 55-75. doi:10.1080/01587911003725022

Organization for Economic Co-operation and Development. (2009). 21st century skills and competences for new millennium learners in OECD countries (Working Paper OECD41). Retrieved from ISTE: http://www.iste.org

Payette, D. L., \& Gupta, R. (2009). Transitioning from Blackboard to Moodle - Course management software: Faculty and student opinions. American Journal of Business Education, 2(9), 67-74. Retrieved from http://journals.cluteonline.com/index.php/AJBE

Pirmoradi, A., Allahyari, M., \& Soluki, M. (2011). The role of knowledge management and elearning in professional development. Archives of Applied Science Research, 3(4), 26-35. doi:10.1504/IJKL.2008.022064

Pollard, H., Minor, M., \& Swanson, A. (2014). Instructor Social Presence within the Community of Inquiry Framework and Its Impact on Classroom Community and the Learning Environment. Online Journal of Distance Learning Administration, 17(2), n2.

Prensky, M. R. (2010). Teaching digital natives: Partnering for real learning. Thousand Oaks, CA: Corwin Press.

Richardson, W. (2010). Blogs, wikis, podcasts, and other powerful web tools for classrooms (3rd ed.). Thousand Oaks, CA: Corwin Press.

Richardson, J., Swan, K., Lowenthal, P. \& Ice, P. (2016). Social presence in online learning: Past, present, and future. In Proceedings of Global Learn 2016 (pp. 477-483). Association for the Advancement of Computing in Education (AACE). Retrieved January 4, 2017 from https://www.learntechlib.org/p/172799. 
Rose, R., \& Smith, A. (2010). Online discussions. In C. Cavanaugh \& R. Blomeyer (Eds.), What works in K-12 online learning (pp. 143-160). Washington, DC: International Society for Technology in Education (ISTE).

Rush, B., Walsh, N. J., Guy, C. J., \& Wharrad, H. J. (2011). A clinical practice teaching and learning observatory: The use of videoconferencing to link theory to practice in nurse education. Nurse Education in Practice, 11(1), 26-30. doi:10.1016/j.nepr.2010.06.001

Sadker, D., \& Zittleman, K. (2006). Teachers, schools, and society: A brief introduction to education. New York, NY: McGraw-Hill.

Schrum, L. M., \& Levin, B. B. (2013). Teachers' technology professional development: Lessons learned from exemplary schools. TechTrends. 57(1), 38-42. Retrieved from http://www.techtrend.us/

Servage, L. (2009). Who is the "professional" in a professional learning community? An exploration of teacher professionalism in collaborative professional development settings. Canadian Journal of Education, 32(1), 149-171. doi:10.1207/s15430421tip4502_8

Simms, J., \& Knowlton, D. S. (2008). Ideas in practice: Instructional design and delivery for adult learners. Journal of Developmental Education, 32(1), 20-30. Retrieved from http://onlinelearningconsortium.org/

Spanneut, G., Tobin, J., \& Ayers, S. (2012). Identifying the professional development needs of public school principals based on the interstate school leader licensure consortium standards. National Association of Secondary School Principals.NASSP Bulletin, 96(1), 67-88. Retrieved from http://www.researchgate.net/

Taylor, J. M. (2011). Characteristics of effective online professional development: A case study analysis of an online professional development course offered via blackboard. (Doctoral 
dissertation). Retrieved from ProQuest Dissertations and Theses database. (AAT $3501375)$

Tella, A. (2011). Reliability and factor analysis of a Blackboard Course Management System success: A scale development and validation in an educational context. Journal of Information Technology Education, 10, 55-80. Retrieved from http://www.jite.org

The Content of Professional Development for Change Toward Differentiation. (2008). In C. A. Tomlinson, K. Brimijoin, \& L. Narvaez, The Differentiated School (pp. 65-107). Alexandria, VA: Association for Supervision and Curriculum Development.

Thomas, T. S. (2010). Online vs. face-to-face: Educator opinions on professional development delivery methods. (Doctoral dissertation). Retrieved from ProQuest Dissertations and Theses database. (AAT 3409126)

Thompson, G. S. (2007, April). A review of transformational leadership models and its linkage to the scholarship/practice/leadership model. Selected Works, 1-18. Retrieved from http://works.bepress.com

Trilling, B., \& Fadel, C. (2012). 21st century skills: Learning for life in our times. San Francisco, CA: Jossey-Bass.

Tucker, C. (2012). Common core standards: Transforming teaching with collaborative technology. Teacher Librarian, 40(1), 30-37,4. doi:10.1007/s11528-013-0668-7

Unal, Z., \& Unal, A. (2011). Evaluating and comparing the usability of web-based course management systems. Journal of Information Technology Education, 10, 19-38. Retrieved from http://www.jite.org 
U.S. Department of Education. (2010, September). Evaluation of evidence-based practices in online learning: A meta-analysis and review of online learning studies (Educational report). Retrieved from http://www.ed.gov/about/offices/list/opepd/ppss/reports.html

Van Kuijk, M. F., Deunk, M. I., Bosker, R. J., \& Ritzema, E. S. (2016). Goals, data use, and instruction: the effect of a teacher professional development program on reading achievement. School Effectiveness and School Improvement, 27(2), 135-156.

Vitale, A. T. (2010). Faculty development and mentorship using selected online asynchronous teaching strategies. The Journal of Continuing Education in Nursing, 41(12), 549-56. doi:10.3928/00220124-20100802-02

Vygotsky, L. S. (1978). The cognitive movement in instruction. Educational Psychologist, 13, 15-29. Retrieved from http://www.tandfonline.com/toc/hedp20/current\#.U6BjMI1dVjs

Webster-Wright, A. (2009). Reframing professional development through understanding authentic professional learning. Review of Educational Research, 79(2), 702-739. doi: $10.3102 / 0034654308330970$

Yoder, M. B. (2001). Is online professional development for you. Learning and Leading with Technology, 29(4), 6-9. Retrieved from http://www.cna.org

Zemke, R., \& Zemke, R. (1995). Adult learning: What do we know for sure? Training, 31(6), 3134. Retrieved from http://synchro.ca/ 